Adetayo, Joshua O. ${ }^{1}$

Faculty of Administration,

Obafemi Awolowo University, Nigeria

Agelebe, Ibiwunmi Bosede

Federal Polytechnic Ede, P.M.B. 231, Nigeria

Bankole, Rebecca Folake

Adeleke University, Ede, Nigeria
ORIGINAL SCIENTIFIC ARTICLE

DOI:10.5937/ekonomika1702015A

Received: February, 25, 2017

Accepted: April, 29, 2017

\title{
CONSUMERS' ATTITUDE ON LOCALLY MADETEXTILES AND ITS IMPACT ON JOB CREATION: THE NIGERIAN EXPERIENCE
}

\begin{abstract}
This study examined consumers' attitude on Made-in-Nigeria textiles and its impact on Job creation in Osun State, Nigeria. It investigated the reaction ofconsumers to locally made textiles, examined how attitudes affect patronage of the productand how consumers' attitudes can either make improve or mar destroy the textiles industry. Primary data was used for this study. Consumers of textiles in Osun state constituted the study population, however, Ede town was purposively selected as the study area, due to the locally made textiles market located in the town which enjoyed patronage from within and outside Osun state. One hundred respondents were randomly selected from the sample area. Questionnaire was used to gather information, thedata gathered were analysed using both descriptive and inferential statistics. Findings revealed mixed attitudes of consumers toward madein-Nigeria textiles. It was observedthat consumers' attitude played a major role in the patronage of the product as revealed by the chi-square statistic $\left(\chi^{2}=30.362\right.$, $p=0.000)$. Likewise, findings showed a positive relationship between consumers' attitudes and the growth of textiles industry but statistically insignificance as $\chi^{2}$ $=14.11$ at $p=0.168$, more also, the result revealed a positive relationship and influence of consumers' attitude on job creation but also not statistically significant as $\chi^{2}=10.371$ at $p=0.409$. The study concluded that patronage of goods was greatly dependent on the attitude of the consumers and this attitude can influence the economic growth and job creation in the country especially in the textile industry.
\end{abstract}

Key Words: Consumers' attitude, local goods, patronage, textiles industry, job creation,

Jel Classification: E24,010

${ }^{1}$ adetayosegun2002@yahoo.com 


\title{
СТАВОВИ ПОТРОШАЧА О ЛОКАЛНИМ ТЕКСТИЛНИМ МАРКАМА И ЊИХОВ УТИЦАЈ НА ОТВАРАҢЕ РАДНИХ МЕСТА: ИСКУСТВО НИГЕРИЈЕ
}

\begin{abstract}
Апстракт
Ова студија истражује ставове потрошача о текстилним маркама у Нигерији и юихов утииај на отварање нових радних места у држави Осун у Нигерији. У студији се темељно истражују реакиије потрошача на локалне текстилне марке, затим се испитује како ставови потрошача утичу на финансијску подршку производа и како они могу било да побољшају било да униште текстилну индустрију. У студији су коришћени примарни подаичи. Потрошачи текстилних марки у држави Осун представљају студијску популащији. Град Еде је одабран као истраживачка област, с обзиром на локалне текстилне марке који су лоциране у граду и које имају фиансијску подрику у држави Осун и ван ње. Стотину испитаника је насумице одабрано из узоркованог подручја. Упитник је коришћен за прикупљање података. Прикупьени подации су анализирани коришћењем дескриптивне и инференичјалне (дедуктивне) статистике. Резулзати показују различите ставове потрошача о текстилним маркама у Нигерији. Уочено је да ставови потрошача имају кључну улогу у финансијској подршщи производа, како открива хи-квадрат тест $(\chi 2=30,362, p=0,000)$. Такође, резултати су показали позитиван однос између ставова потрошача и раста текстилне индустрије, али статистички несигнификантан $\left(\chi^{2}=14,11, p=0.168\right)$, баш као и позитиван однос и утицај ставова потрошача на отварање нових радних места, али не и статистички значајан ( $\chi 2=10,371, p=0.409)$. У закључки студије указује се да финансијска подрика производима у великој мери зависи од ставова потрошача и да ставови потрошача могу утицати на економски раст и отварање нових радних места у земљи, посебно у текстилној индустрији.
\end{abstract}

Клучне речи: ставови потрочача, локални производи, финансијска заштита, текстилна индустрија, отварање радних места

\section{Introduction}

Nigeria is a country blessed with abundance of both human and natural resources that if properly and positively utilized will bring development to the country. It is a nation occupied with different people of diverse culture, beliefs, attitudes, habits and behaviours with under development indices such as unemployment, high rate of poverty level, high rate of violence, lack of access to accurate information. However, Nigerian government over the years had put up some measures to solve most of the challenges with programmes such as; Operation Feed the Nation (OFN) in 1976, Family Economic Advancement Programme (FEAP) in 1997, Family Support Programme (FSP) in 1997, National Poverty Eradication Programme (NAPEP) in 2001, Nigeria Agricultural Development Fund (NADF) in 2002, National Economic Empowerment Development Strategy(NEEDS) in 2003, Commodity Marketing and Development Companies 
(CMDC) in 2003 and the introduction of entrepreneurship education in the tertiary institutions in the nation.

However with all the above stated policies, it should be noted that for any developing country seeking to achieve economic growth, such country should endeavour to reduce importation to the barest minimum and utilize locally resources, even if not having the required production capacity for export purposes. In Nigeria for instance, those products that are manufactured locally are referred to as "Made-in-Nigeria goods" (Oladele \& Arogundade, 2011). Though, Nigerian consumers has access to several products from around the world, the abundance of foreign brands of many kinds of products in Nigerian markets make it easy for consumers to satisfy their yearnings for these imported items (Asen, Eke \& Kalejaye, 2011). These imported goods in particular textiles have jeopardize the economic growth in the country, thereby leading to unemployment and other social vices. Ekerete, (1996) and Okeafor, (1996) opined that there has been a wide outcry from economy watchers and analysts about a perceived ugly trend observed on the attitude of indigenous consumers on locally-made Nigeria products. The complaint is that Nigerian consuming public shy away from purchasing made-in-Nigeria goods and prefer foreign-made ones instead. Some commentaries have attributed this trend to the way these consumers perceive the locally made products especially when they compare them with their foreign alternatives. Their perception of locally-made textiles, for instance, as inferior, or of poor quality, improperly designed, and less 'satisfying', is said to be the reason for their poor patronage of these products. As a result, indigenous companies and infant industries that produce and market textiles locally easily crumble in the face of competition from those that deal in foreign textiles Moreso, increasing globalization of world trade and Nigerian's continuous trade liberalization has encouraged dumping of foreign goods in the country thereby making marketing of home-made goods not only difficult, but in some cases almost impossible. Over the last decade, Nigerian manufacturers have been enmeshed in a dilemma, borne out of ensuring long-term survival in an atmosphere of ever increasing product cost, and ever-decreasing consumer purchasing power (Akomolede \& Oladele, 2008).

Industries in Nigeria have long been crying of unfair competition from foreign products that find their way into the country through unauthorized means (Gado \& Nmadu, 2011). Many industries have been closed down as they were unable to compete favourably with their counterpart companies in the foreign countries due to the attitude displayed by the Nigerian consumers in patronizing the foreign goods at the expense of the locally-made goods. Due to this, the Nigerian manufacturing sector has witnessed declining capacity utilization resulting in reduced labour force (Obadan, 1998). The textile industry, a major player in manufacturing, appears to be on the fore front of this decline with reports of textile companies closing down on a yearly basis (Obadan, 1998; Jibrin, 2002; Gado \& Nmadu, 2011).

Therefore, for Nigeria to develop entrepreneurially, reduce unemployment and create job for the masses, emphasis should be placed on consumers' attitudes towards the made-in-Nigeria goods in particular textiles. 


\section{Statement of the Problem}

So many factors have been identified and attributed to have been the reasons for slow rate in entrepreneurship development in the country. Several scholars have talked about many factors hindering job creation, Arowomole and Oyedokun (2012) identified factors such as lack of variable concept, lack of market familiarity, lack of technical skills, lack of seed capital, lack of business know-how. Other authors such as Obasan (2005) had seen unavailability of required labour, raw material inputs, degree of inflation, lack of technological development, political climate, market and capital, poor-infrastructural facilities, lack of access to accurate information, religion and cultural unrest.

Aremu (2005) in Gadoand Nmadu (2011) opines that massive importation coupled with high cost of production resulted in the closing down of 65 local textile mills, rendering about 150,000 workers jobless is one of the factors that have affected the textiles industry in Nigeria. He almost concluded that the sector had collapsed with unpalatable implications to the nation by way of unemployment, poverty and social vices. Moreso, Ayodele (1998) in Gado and Nmadu (2011) described the public electricity in Nigeria as "Energy crises" and stated that power supply, particularly electricity and petroleum, are crucial to the operation of the textiles companies. Gadoand Nmadu (2011) stated that Ati (1985) and Ubani (1983) identified some performance limiting factors in the Nigerian business environment amongst which are: problems of raw materials and equipment importation, inter-organizational relations, Governmental and parent - organization regulation and interference, indiscriminate importation and smuggling, and inadequate capital and skilled labour. According to them researches had further shown that poor infrastructures have hampered the progress of textile companies in Nigeria, making companies to provide their own power, a situation (Obadan, 1998) refers to as BOYI meaning "Build Your Own Infrastructure" and that this decline in electricity supply has resulted in the decline on the performance of Textiles Industry.

Eneji, Onyinye, Kennedy and Rong (2012) identified technological gaps in the industry, stating that the modernization of spinning capacity is generally lagging behind technological improvements in the weaving mills; low capacity unitization on the part of labour productivity in spinning operations and inadequate provision for onthe-job training as factors affecting Nigeria Textiles Industry. They further stressed that the dependence of Nigeria textile businessmen on liberal import from Chine and other countries does not necessarily lead to growth in the Nigeria Textile Industry.

However, the preceding empirical evidences had shown that job creation in the textile industry in Nigeria had been attributed to several factors. These factors include lack of technological development, inflation, underdeveloped market, lack of capital, poor infrastructural facilities and lack of access to accurate information. However, there is no conclusive study on the perspective of consumers'attitude. The need to examine this attitude perspective is necessitated by its capacity to serve either as incentive or otherwise to job creation in the Nigeria's textile industry. 


\section{Research Objectives}

The broad objective of this study was to investigateconsumers' attitude onlocally made- textiles and its impacts on job creation in Osun State, Nigeria.

The specific objectiveswere to:

i. $\quad$ examine the perception of consumers to locally made textiles;

ii. examine how attitude affects patronage of locally made products;

iii. determine how consumers' attitudeinfluences the growth of textiles industry;

iv. examine how consumers'attitudetowards locally made textiles affects job creation in thetextiles industry.

\section{Literature Review}

Consumers are individuals with likes and dislikes. When the preponderance of people in a particular group feel one way or another about a product, service, entity, person, place or thing, it is said to be a generalized consumer attitude that could affect the marketing of that person, product or entity in positive or negative ways.

Consumers' attitude is consumers' overall, enduring evaluation of a concept or object, such as a person, a brand, a service. An attitude is not fleeing; it is an orientation that lasts over time. An attitude is general in that it summarizes consumers' evaluations over a wide range of situation. Attitudes are important because they reflect what consumers think and feel. They also can be used to explain what the consumers intend to do. The thinking portion of the attitude is called a cognition while the feeling or hedonic portion relates to emotion.

\subsection{Components of Consumers' Attitude}

Consumer attitudes are a composite of a consumer's (1) beliefs about, (2) feeling about, and (3) behavioural intentions toward some object-within the context of marketing, usually a brand or retail store. These components are viewed together since they are highly interdependent and together represent forces that influence how the consumer will react to the object.

Beliefs: The first component is belief. A consumer may hold both positive beliefs toward an object as well as negative beliefs. In addition, some beliefs may be neutral and some may be differing in valance depending on the person or the situation. The beliefs that consumers hold need not be accurate, and some belief may, upon closer examination, be contradictory.

Feelings / Affect: Consumers also hold certain feelings toward brands or other objects. Sometimes these feelings are based on the beliefs, but there may also be feelings which are relatively independent of beliefs.

Behavioural Intention: The behavioural intention is what the consumer plans to do with respect to the object (e.g., buy or not buy the brand). As with affect, this is sometimes a logical consequence of beliefs (or affect), but may sometimes reflect other circumstances (Wikipedia, 14 ${ }^{\text {th }}$ Dec., 2012). 


\subsection{The Status of Textile Industry in Nigeria}

Nigeria is the largest country in black Africa with a population forecast of 150 million people broken into 36 states with Abuja as the Federal Capital. With this population and clothing being a basic need of life, it is evidently clear that Nigeria constitutes a very large market for textile materials (Njoku, 2004).

The textile industry of Nigeria is said to be the third largest in Africa after Egypt and South Africa. The industry is mainly controlled by large private-sector and it is the largest employer of labour in the manufacturing sector, it accounts for about 25 percent of total manufacturing employment (Wikipedia, $14^{\text {th }}$ Dec., 2012).

The Gross National Product or Gross Domestic Product of Nigeria and the per capita income can question sustain a vibrant textile industry to satisfy the domestic market and export if possible, ironically this is not the case.

According to Njoku (2004), he states that in 1990, there were 175 textiles factories operating in Nigeria but as of today it has reduced to 42 epileptic operators and it is only 12 of these that can boast of operating at $30 \%$ capacity. He further stated that the investment and savings policies of 1960s induced steady growth which gave rise to an average of $12.5 \%$ growth rate in the $1970 \mathrm{~s}$. The recession of the early to mid (1980) dealt with the industry and took its toll. The cumulative Textile Production indeed (1972 - 2000) declined from 4271 to 171.1 in 1984 and 112.8 in 2003. The industry recovered in the late 1980s achieving an annual growth rate of about $67 \%$ between 1985 and 1991 .

The industry was the largest employer of labour in the manufacturing sector within these periods. Capacity utilization integration programme embarked upon by many firms in the industry in compliance with the government policy issued in the mid-1980s was positive contributing factor. Thus, the level of domestic sourcing of raw materials witnessed a steady improvement from $52 \%$ in $1987,57 \%$ in 1988 to $64 \%$ in 1991 . However, this improved performance was not universal among the firms in the industry. The few producers of lace textiles who were producing less than $20 \%$ of the total textiles output in 1980 dropped to $12 \%$ in 1994 and less than $8 \%$ in 2003 . This declined could be traced to the quality and quantity of the type of cotton used. For other types of textiles production, the level of local raw materials usage increased because they could be obtained locally while that of the lace material can only be imported (Wikipedia, $14^{\text {th }}$ Dec., 2012).

The Nigeria Textile Industry represents, a strategy non-oil industry for Nigeria, though under developed but a potential investment and industrialization in sub-Sahara / African, size and population; the third largest textile industry in Africa after Egypt and South-Africa; the world largest but singular consumer of lace products of annual demand of about $32.8 \%$ of the global output; on replacement basis, the present installed textile manufacturing capacity in Nigeria represents $£ 3$ billion investment. Although operating at about $25 \%$ capacity in 2003 , the current production is approximately $\$ 281.25$ million. (Wikipedia, $14^{\text {th }}$ Dec. 2012).

In the year 2000, Nigeria Textile Industry produced about 500 million metres of all types of fabrics. In 2002 they produced $72 \%$ of the West Africa production with the embroidered lace contributing only 12\% (World Trade Organization Annual Bulletin, 2003) in Njoku (2004). He further stressed that, despite the fact that Nigeria has favourable trade agreements, its export declined whilst its imports increased dramatically leading 
to a situation that the Nigeria Textile Industry has a market share of about $34 \%$ in the home market.

\subsection{Factors Contributing to Nigeria's Crisis Ridden Clothing and Textile Industry}

Wikipedia (December 2012) posted out some factors which were seen to have contributed to the decline of textiles industry in Nigeria:

Trade Policies: Prior to the mid $-50 \mathrm{~s}$, Nigeria had a successful agricultural industry, exporting cash crops like cotton, cocoa and groundnut. The success of the agricultural industry paralleled with that of textiles. Textiles and agriculture went hand in hand as agriculture provided the raw material i.e. cotton in the first step of the textile supply chain. By the mid $-50 \mathrm{~s}$, however, the agricultural boom came to an end. Post 1960, attaining its independence and embracing nationalism, Nigeria adopted an import substitution strategy. This translated to control on cotton prices and high tariffs, among many tactics used, on imported textiles. From 1967 - 70 (the Biafra War) and later 1977, there was an outright ban on imported textiles. These bans were meant to provide leverage for Nigeria in its dealings with its trading partners. In fact, the 1977 ban, for example, was the result of what the government deemed a self-sufficient clothing and textile industry. The government, arguably, got it right.

As of 1980, Nigeria was ranked the third largest textile industry in Africa after Egypt and South Africa. However, amidst the oil boom of the 70 s to 80 s, Nigeria became over reliant on oil, to the detriment of its agricultural sector. Cotton production, for example, was in the 1980s, fifty percent below its production capacity. There was nothing in place to actively stop its rapid decline. Nigeria engaged in a culture of high consumption but produced less. By 1874, Nigeria was importing simple basics like food. By 1985 things got worse and a year later, Structural Adjustment Program (SAP) was introduced. SAP ran from 1986 to 1988 and was defined as a period of massive devaluation of the Naira.

Raw Materials: from 1903 to 1974, the British Cotton Growers Association was in place to help regulate and advocate for Cotton Growers. By 1974, it was replaced with the Nigerian Cotton Marketing Board who retained the same functionalities including added functions of marketing its cotton. By 1986, however, the year SAP was implemented, the board was abolished. What would follow, especially with no oversight, was a further deterioration within the cotton industry in terms of production capacity. This meant the textile industry had insufficient and at times no raw materials to work with. As a result, fabric manufacturers relied heavily on imported raw materials and other textile inputs to even begin fabric production.

Outdated Equipment: The massive devaluation of the Naira, however, made it impossible for manufacturers to even afford imported textile and textile inputs. Further, even fabric designers that could afford raw materials had to contend with outdated and run down equipment. The use of outdated equipment was, needless to say, crippling as it forced fabric designers to operate well below capacity. For instance, in 1986, the industry was performing at $37 \%$ below capacity utilization. By 1998 , it had diminished to $28 \%$.

Infrastructural Issues and Unemployment: Exacerbating the problems above were infrastructural issues, particularly power supply. The constant power failure, also caused by a Nigeria Electric Power Authority (NEPA) now Power Holding Company 
of Nigeria (PHCN) operating well below its 6,000 MW capacity, made it extremely difficult for textile businesses to see a return on investments much less break even. The corresponding result was heavy retrenchments, huge turnover rates with the adverse effect of erosion of skilled workers, factory closures, riots and chaos.

Further, although Nigeria, especially during the import substitution era of the 70s had tried to make most of its textile plants Nigerian owned, the fact remained that foreigners had the major market share. In 1986, for instance, according to extensive research conducted by Swedish researchers on the union power in Nigeria's textile industry, Nigeria's Textile Manufacturer Association reported 75 members. Of these 75, 30 were Indian owned firms with the rest being Chinese and Lebanese. Only 4 of the 75 were reported as indigenous Nigerian owned firms. Amidst all the instability, huge operational cost, riots and corruption, these foreigners returned to their countries of origin. Sometimes, they left just as quickly as they had appeared leaving no retrenchment benefits.

Corruption: Adding fuel to the already burning fire of the textile industry was the government's corruption practices. Despite the billions made from oil revenues, the Nigerian government had nothing to show. Oil monies had been used to sustain Nigeria's addiction on imported products, engage in excesses and embezzlements. For instance, in the $80 \mathrm{~s}$, the government built a $\$ 2.4$ billion smelter. The cost was $60-100 \%$ higher than what it would have cost to build the smelter in a developed country.

"Bend Down Select" and Chinese Imports: The above factors along with trade liberalization policies adopted in the 90s, opened the floodgates for Second Hand Clothing a.k.a. "bend down select" from the West and later Chinese goods. Specific to the "bend down select" market, affordability reigned supreme as Nigeria could no longer afford to cloth its own citizens. Specific to Chinese imports, neither Nigeria nor the world anticipated the threat China would pose for textile companies in the West and developing countries.

Prior to 1974, the USA along with other European countries made up members of GATT, had signed trade agreements that restricted trade in cotton production with its exporting countries. Further restrictions came in 1974 with the establishment of the Multi Fiber Arrangement (MFA), a system of quotas which restricted all importation of textile goods from developing countries, with the exception of silk. MFA was set to expire in December of 2004. What appeared unanticipated was that China would join the World Trade Organization (WTO). China joined the WTO in 2001 and by 2003, it had 17\% of the world's textile market share. Meanwhile, in 1995, the WTO enacted the Agreement on Textiles and Clothing (ATC). The purpose of the ATC, a multilateral instrument, was to eliminate textile quotas for all WTO members by January $1^{\text {st }}, 2005.2006$, China was the largest producer of apparel / textile products in the world.

With China's strong emergence on the apparel / textiles world map, it flooded other countries' domestic markets, across the globe, with its cheap imports. Meanwhile, African countries like Nigeria who finally saw restrictions on trade lifted and were waiting to take a big bite out of the Western apple, where now having to contend with China.

Nigeria matched against China was simply not a threat. For Nigeria's textile industry, the lack of diversity and innovation in textile designs plus the aforementioned factors, made it extremely vulnerable. Chinese textile mills outpaced Nigeria in 
production capacity, labour / skilled workers, regulatory compliance in exporting to Western countries and innovative equipment. Worse, the Chinese did not spare Nigeria in its domestic market. The Chinese mastered and produced Nigeria designs like "ankara" and "asooke", stamped "made in Nigeria" on them and sold them in Nigeria as local products.

The affordability saw consumers shunning the more expensive and genuine Nigeria textiles for China's cheap import, Nigeria's already stressed out textile industry saw even more factory closures, retrenchments, and lesser production capacity.

While the government attempted to put a bandage on the wound inflicted by the Chinese, the mind set of Nigerians and corruption practices made it very hard to enforce. As such, there has been ongoing and overwhelming smuggling of Chinese goods into the country undermining government efforts (Wikipedia, 14 ${ }^{\text {th }}$ Dec. 2012).

\subsection{The Need for Job Creation}

According to the Nigerian Bureau of Statistics (NBS), the country's unemployment rate has increased to 9.9 percent in the third quarter of 2015 , representing a fourth consecutive rise in the unemployment rate since the third quarter of 2014. The Bureau revealed that a total of $1,454,620$ Nigerians are unemployed in this quarter compared to 529,923 in the second quarter and this has led to an increase from 8.2 percent in second quarter 2015 to 9.9 percent in third quarter 2015. Therefore, there is an urgent need to create jobs so as to accommodate the unemployed and to reduce the level of unemployment to the barest minimal.

\section{Methodology}

Descriptive research design was adopted so as to unravel the essential elements and characteristics of the concepts under investigation and also to analyse the relationships that exist between the variables of interest.

The study covered OsunState; the state is one of the states under southwestern zone in Nigeria. The state is made up of thirty local governments. However, Ede-North local government was purposively selected for the study, this was due to the relevance of the town to the study at hand. Ede is majorly known as an area that is specialized in local textiles making in the state, and also because of the local textiles market situated in the town that enjoys the patronage of people both locally and internationally.

The study employed primary source of data, 100 respondents were randomly selected for the study. A structured questionnaire was administered on the qualified respondents of the study. However, from the 100 respondents whom the questionnaire was administered on, only 94 respondents returned the answered questionnaire.

The research objectives for this study were achieved with the use of descriptive and inferential statistics Descriptive statistics like percentages, tabulation, graphs, and frequency distribution were used to analyse the data. Inferential statistics techniques were used in testing the relationship between the dependent and the independent variables, while chi-square analysis technique was adopted to measure the effect of the independent 
variable (consumers' attitudes on made-in-Nigeria textiles) on the dependent variable (job creation).

\section{Findings and Discussion}

Consumers expressed their diverse perception on the locally made products as shown in Table 1. The table depicted that respondents with negative attitude towards made-in-Nigeria textiles were approximately $44 \%$, while $49 \%$ respondents were positive and $7 \%$ respondents were indifferent. This reveals mixed attitudes towards made-inNigeria textiles. However, larger percentage are of positive attitude towards made-inNigeria textiles.

Table 1: Consumers' Attitudes Towards Made-in-Nigeria Textiles

\begin{tabular}{|cc|c|c|c|c|}
\hline \multirow{2}{*}{ Variables } & Frequency & Percentage & Valid Percentage & \multirow{2}{*}{ Cumulative Percentage } \\
\cline { 2 - 4 } & & 46 & 48.9 & 48.9 & 48.9 \\
\hline Valid $\quad$ POSITIVE & 41 & 43.6 & 43.6 & 92.6 \\
\hline & NEGATIVE & 7 & 7.4 & 7.4 & 100.0 \\
\hline & INDIFFERENCE & 94 & 100.0 & 100.0 & \\
\hline
\end{tabular}

Source: Survey, 2016

\section{Frequency}

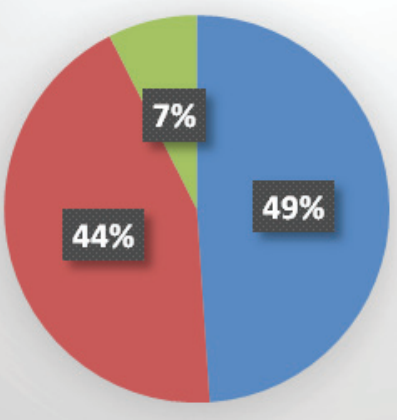

- Positive

- Negative

Indifference

Source: Survey, 2016 
Table 2 revealed that $29.8 \%$ respondents stronglydisagreed that patronage is not being determined by consumers' attitude, $27.7 \%$ disagreed, while $17 \%$ and $10.6 \%$ agreed and strongly agreed respectively. Therefore, from the analysis by the level of agreement of respondents, it can easily be inferred that patronage of product is determined by consumers' attitude on that product.

Table 2: Patronage is not Determined by Consumer's Attitude on the Product

\begin{tabular}{|c|c|c|c|c|c|}
\hline & & Frequency & Percentage & $\begin{array}{c}\text { Valid } \\
\text { Percentage }\end{array}$ & $\begin{array}{l}\text { Cumulative } \\
\text { Percentage }\end{array}$ \\
\hline Valid & NO RESPONSE & 4 & 4.3 & 4.3 & 4.3 \\
\hline & STRONGLY DISAGREE & 28 & 29.8 & 29.8 & 34.0 \\
\hline & DISAGREE & 26 & 27.7 & 27.7 & 61.7 \\
\hline & NEUTRAL & 10 & 10.6 & 10.6 & 72.3 \\
\hline & AGREE & 16 & 17.0 & 17.0 & 89.4 \\
\hline & STRONGLY AGREE & 10 & 10.6 & 10.6 & 100.0 \\
\hline & Total & 94 & 100.0 & 100.0 & \\
\hline
\end{tabular}

Source: Survey, 2016

The chi square statistic as shown in table 3 revealed that patronage depends on consumers' attitude since the $\chi^{2}=30.362$ and P-value 0.000 . Therefore, with the $\mathrm{P}$-value being less than 0.05 significance level, this indicates that consumers' attitude is statistically significant to patronage.

\section{Table 3: Chi-Square Tests}

\begin{tabular}{|l|l|l|l|}
\hline & Value & Df & Asymp. Sig. (2-sided) \\
\hline Pearson Chi-Square & $30.362^{\mathrm{a}}$ & 6 & .000 \\
Likelihood Ratio & 36.191 & 6 & .000 \\
Linear-by-Linear Association & 4.735 & 1 & .030 \\
N of Valid Cases & 94 & & \\
\hline
\end{tabular}

Table 4 below revealed that 33\% respondents strongly agreed and $42.6 \%$ agreed that consumers' attitude on made in Nigeria textiles could either mar or make the industry while $3.2 \%$ strongly disagreed, $8.5 \%$ disagreed, $8.5 \%$ neutral and $4.3 \%$ gave no response. Therefore, with the level of respondents' agreement to the statement, it can be deduced that consumers' attitude has impact on the textiles industry, 
Table 4: Consumers'Attitude on Made in Nigeria Textiles Could Either Mar or Make the Industry

\begin{tabular}{|c|c|c|c|c|c|}
\hline & & Frequency & Percentage & Valid Percentage & $\begin{array}{l}\text { Cumulative } \\
\text { Percentage }\end{array}$ \\
\hline Valid & NO RESPONSE & 4 & 4.3 & 4.3 & 4.3 \\
\hline & STRONGLY DISAGREE & 3 & 3.2 & 3.2 & 7.4 \\
\hline & DISAGREE & 8 & 8.5 & 8.5 & 16.0 \\
\hline & NEUTRAL & 8 & 8.5 & 8.5 & 24.5 \\
\hline & AGREE & 40 & 42.6 & 42.6 & 67.0 \\
\hline & STRONGLY AGREE & 31 & 33.0 & 33.0 & 100.0 \\
\hline & Total & 94 & 100.0 & 100.0 & \\
\hline
\end{tabular}

Source: Survey, 2016

The chi-square statistic as shown in table 5 revealed $\chi 2$ value of 14.110 and p-value of .168, this implies that though there is positive relationship between consumers' attitude and the growth of the textiles industry but consumers' attitude to the industry growth is statistically insignificance as p-value is greater than 0.05 level of significance.

Table 5: Chi-Square Tests

\begin{tabular}{|l|c|c|c|}
\hline & Value & Df & $\begin{array}{c}\text { Asymp. Sig. } \\
\text { (2-sided) }\end{array}$ \\
\hline Pearson Chi-Square & $14.110^{\mathrm{a}}$ & 10 & .168 \\
\hline Likelihood Ratio & 17.117 & 10 & .072 \\
\hline Linear-by-Linear Association & 1.767 & 1 & .184 \\
\hline N of Valid Cases & 94 & & \\
\hline
\end{tabular}

Table 6 depicts that consumers' attitude can influence job creation, as $54.3 \%$ respondents strongly agreed, $28.7 \%$ agreed while $10.6 \%$ were neutral, $4.3 \%$ gave no response, $1.1 \%$ and $1.1 \%$ were strongly disagreed and disagreed respectively. Therefore, the result revealed the importance of consumers' attitude on job creation in the textile industry, as larger percentage agreed that consumers' attitude can influence job creation.

Table 6: Continued and Increased Production with Profitability will Provide Bases for Job Creation

\begin{tabular}{|c|c|c|c|c|}
\hline & Frequency & Percentage & $\begin{array}{l}\mathrm{V} \text { a l i d } \\
\text { Percentage }\end{array}$ & $\begin{array}{l}\text { C u m l a t i v e } \\
\text { Percentage }\end{array}$ \\
\hline Valid NO RESPONSE & 4 & 4.3 & 4.3 & 4.3 \\
\hline STRONGLY DISAGREE & 1 & 1.1 & 1.1 & 5.3 \\
\hline DISAGREE & 1 & 1.1 & 1.1 & 6.4 \\
\hline NEUTRAL & 10 & 10.6 & 10.6 & 17.0 \\
\hline AGREE & 27 & 28.7 & 28.7 & 45.7 \\
\hline STRONGLY AGREE & 51 & 54.3 & 54.3 & 100.0 \\
\hline Total & 94 & 100.0 & 100.0 & \\
\hline
\end{tabular}

Source: Survey, 2016 
More so, the chi-square statistic shown in table 7 revealed $\chi 2$ value of 10.371 and p-value of 409 , this implies that although there is positive relationship between consumers' attitude and job creation in the textiles industry, consumers' attitude is not statistically significant to job creation as p-value is greater than 0.05 level of significance.

Table 7: Chi-Square Tests

\begin{tabular}{|l|c|c|c|}
\hline & Value & Df & Asymp. Sig. (2-sided) \\
\hline Pearson Chi-Square & $10.371^{\mathrm{a}}$ & 10 & .409 \\
\hline Likelihood Ratio & 13.432 & 10 & .201 \\
\hline Linear-by-Linear Association & 2.411 & 1 & .121 \\
\hline N of Valid Cases & 94 & & \\
\hline
\end{tabular}

Source: Survey 2016

\section{Recommendations for future researches}

The facts obtained from the findings and conclusion of this study provides sufficient ground to recommend that policies that will encourage positive attitude and high patronage of the locally produced goods in particular textiles should be enforced by the government. Also, the government should not be biased in concentrating attention to only one sector of the economy, oil business alone can not foster the needed growth in the nation.Other industrial sector should be given appropriate attention as this will also provide adequate employment. The government should pay serious attention to border effects as they affect the flow and availability of goods traded internationally and domestically as confirmed by Evans (2003) in Njoku (2004) as this will help in checkmating the rate of textile dumping in the country.

In order to increase the quality of the product, the Standard Organiation of Nigeria and all other agencies overseeing the standard of products in Nigeria need to be awaken to perform their duties effectively and judiciously.

Also, to the manufacturers of the textiles in Nigeria, product quality should be a major concern, as this will increase patronage and profitability.

Nigeria consumers should be aware of the fact that favourable attitude towards foreign textiles at the expense of locally made ones will have negative implications on per capita domestic productivity. They should be made to know that consuming foreign textiles at the expense of made in Nigeria textiles will generate income for the foreign country at the expense of the domestic country, thereby developing the foreign country instead of own country. Hence, there is a need for consumers to disabuse their mind from the subconscious enslavement inherent in the consumption of foreign products, textiles in particular and embrace our own products so as to create jobs and develop the industries in the country. 


\section{Conclusion}

Findings revealed that consumers are of mixed attitudes towards made in Nigeria textiles, some have a positive attitude, some negative while others are indifferent. Result also shows that patronage of made-in-Nigeria textiles is influenced by the attitude of consumers, this implies that consumers' attitude towards the locally made textiles has a great extent to determine if the product will enjoy patronage of consumers or not. Also, it was unveiled that larger percentage of consumers are of the opinion that attitude towards textiles made in Nigeria can either make or mar the industry, respondents are of the view that if consumers' attitude are favourably disposed to made-in-Nigeria textiles and backed up by good patronage of the product, this will help the textiles industry. Likewise, respondents are of the view that consumers' attitude can affect job creation in the state, though not statistically significant, it was believed that if the industry is doing well through increased productivity and profitability made possible by the patronage enjoyed from Nigerian consumers, this will aid job creation thereby reducing the level of unemployment in the state and in Nigeria as a whole.

\section{References}

Aire J. U. (1973). Consumer Attitudes to Made in Nigeria Goods and Implication for Marketing. In O. Iyanda (ed.), Marketing Theory for Practitioners (pp.46-62). Lagos, Nigeria: Nigerian Institute of Management.

Akomolede, T. I. \& Oladele, P. O. (2008). Marketing and Consumer Protection Laws as applicable to the manufacturing sector in Nigeria: An empirical analysis. International company and commercial law review, 19(8), 265-272.

Aremu, I.O. (2005). Collapse of the Textile Industry in Nigeria: Implications for Employment and Poverty Eradication. Kuru.

Arowomole, A. M., \& Oyedokun, T. A. (2012). Entrepreneurship: Structure \& Practice. Ibadan, Oyo State: Aseda Publishing

Asen O. S., Eke V. I. \& Kalejaye A. S. A. (2011). Women's Attitude to "Made in Nigeria" Wears in BauchiMetropoli. Journal of science and public policy, 3.

Ati, R.I. (1985). Perceiving the Environment: Its Relationship with Values and Cognitive Process: An Empirical Study of Nigerian Managers. Jos: University of Jos.

Ekerete, P.P (1996). Factors influencing consumers' choice of retail stores. In Nwokoye, N. G. \& S.E Kalu, (Eds), Retailing in Nigeria. Umuahia: Hercon Publishers Limited.

Eneji, M.A.,Onyinye, I.J., Kennedy, D.N. \& Rong, S.L.(2012). Impact of Foreign Trade and Investment on Nigeria's Textile Industry: The Case of China. Journal of Africa Studies Development, 4(5), 130-144.

Evans, L. C. (2003). Border effects and the availability of domestic products abroad. In Njoku, U.A. (ed.), Marketability of Made-in-Nigeria Textiles Material. Cambodia: St. Clement University. 
Gado, N.D., \&b Nmadu, T.M. (2011). The Performance of Textile Companies in the North West Zone of Nigeria: The Role of Infrastructure as a Resource. International Journal of Human Resource Studies, 2(1), 89-100.

Jibrin, W. (2002). Situation Report on The Nigerian Textile Industry and the Way forward: A brief presentation. Unpublished paper Presented at a Seminar organised by The National Union of Textiles, Garment and Tailoring Workers of Nigeria.

Kalu, S.E., \& Ikwuegbu, N.I. (2000). Consumers' Perception of Locally-Made Goods in Nigeria, the Experience of Selected Firms in the Textiles Industry. JIBER, 4(1).

Njoku, U.A. (2004). Marketability of Made-in-Nigeria Textiles Material. Cambodia, St. Clement University

Obadan, M. I. (1998). Managing the Nigerian Economy into the Next Millenium: Strategies and Policies. Journal of Economic Management, 5(1):1-38.

Obasan, K.A. (2005). Entrepreneurship Theory and Practice. Ijebu-Ode, Gratia Associates International.

Okafor, U.S (1996). Consumers' Purchases Sacrifices in Nigeria, In Nwokoye, N.G \& S.E. Kalu, (Eds.), Retailing in Nigeria. Umuahia: Hercon Publishers Limited.

Oladele, P.O. \& Arogundade, K.K. (2011). Attitudes of University Students Towards Made-in-Nigeria Textiles Products. African Journal of Scientific Research, 5(1)

Vuković, A., Đoković, G., \& Rončević, D. (2015). Neophodnost rešavanja nezaposlenosti mladih. Ekonomika, 61(1), 173-182.

www.nbs. Unemployment Rate in Nigeria. Retrieved August 8, 2016. 